\title{
Th-U-Pb Dating of Lunar Granites by X-Ray Microanalysis
}

\author{
S.M. Seddio, B.L. Jolliff, R.L. Korotev, and P.K. Carpenter \\ Dept. of Earth and Planetary Sciences (EPS) and McDonnell Center for the Space Sciences, Washington \\ University, One Brookings Dr., St. Louis, MO 63130 USA
}

Granitic rocks are rare among returned lunar samples [1], and the timing of the formation of lunar granite is still debated $[1,2,3]$. Conventional isotopic methods of geochronology typically require sample consumption-an undesirable requirement for uncommon lithologies. Geochronology using EPMA is a non-destructive alternative. Extended fractional crystallization, a process involved in lunar granite petrogenesis, concentrates incompatible elements (e.g., Th, U, Zr) in the liquid relative to the common crystallizing minerals. Lunar granites ultimately crystallize from the Th-, U-, and Zr-rich residual liquids. The major isotopes of $\mathrm{Th}$ and $\mathrm{U}$ are radioactive and all decay to $\mathrm{Pb}$. In lunar granites, $\mathrm{Th}$ and $\mathrm{U}$ are typically concentrated in trace minerals such as monazite, yttrobetafite, zirconolite, apatite, and merrillite (ideally, [La,Ce,Nd] $\mathrm{PO}_{3},[\mathrm{Y}, \mathrm{Ca}, \mathrm{Th}, \mathrm{U}, \mathrm{Fe}, \mathrm{REE}]_{5}[\mathrm{Ti}, \mathrm{Nb}]_{5} \mathrm{O}_{17}$, $[\mathrm{Ca}, \mathrm{REE}] \mathrm{ZrTi}_{2} \mathrm{O}_{7}, \mathrm{Ca}_{5}\left(\mathrm{PO}_{4}\right)_{3}$, and $\left.\mathrm{Ca}_{3}\left(\mathrm{PO}_{4}\right)_{2}\right)$, and rarely thorite ([Th, $\left.\left.\mathrm{U}\right] \mathrm{SiO}_{4}\right)[1,4]$. These minerals do not incorporate $\mathrm{Pb}$. Our analyses of these phases show that they each include several wt $\%$ of $\mathrm{Th}, \mathrm{U}$, and $\mathrm{Pb}$ from which we calculate crystallization ages of two Apollo 12 granite samples.

Phases were identified using EDS (Fig. 1) and WDS using the Washington University EPS JEOL JXA-8200 Superprobe. We used WDS wavescans to confirm the elements present and identify background positions for use in all standards and samples. Phase compositions were determined by quantitative EPMA done at $15 \mathrm{kV}$ accelerating voltage and $25 \mathrm{nA}$ probe current. For $\mathrm{Th}, \mathrm{U}$, and $\mathrm{Pb}$, we counted the $\mathrm{M} \alpha \mathrm{X}$-ray line on-peak for $30 \mathrm{~s}$ and off-peak for $15 \mathrm{~s}$ on a high-intensity PETH H-type spectrometer. Our measurements were made on a sealed $\mathrm{Xe}$ detector which does not exhibit the Ar absorption edge adjacent to the $U \mathrm{M} \beta$ peak - a major issue for measurement of $U$ in materials. Probe for EPMA software (Probe Software, Inc.) was used for analysis and data correction including peak interference corrections (e.g., Th $\mathrm{M} \beta$ on $\mathrm{U} M \alpha$ ). Due to electron transmission through micron-sized grains and secondary fluorescence, all thorite analyses contain some component of adjacent or underlying phases (frequently silica and/or feldspar; Table 1; Fig. 1). Analytical standards included synthetic and natural silicate, oxide, and REE glass standards of [5] and [6] for primary calibration, which were checked against secondary standards.

Following the method of [7], we calculated the crystallization ages of Apollo 12 granites 12023,147-10 and 12032,366-19 from our analyses of thorite, yttrobetafite, and monazite in 12023,147-10 and zirconolite in 12032,366-19 (Table 2). We assumed that all analyzed $\mathrm{Pb}$ is radiogenic which is valid since $\mathrm{Pb}$ should not be present in the analyzed minerals beyond trace concentrations. Given that assumption,

$$
\mathrm{Pb}=\frac{\mathrm{Th}}{232}\left(\mathrm{e}^{\lambda^{232} \mathrm{t}}-1\right) 208+0.9928 \frac{\mathrm{U}}{238.04}\left(\mathrm{e}^{\lambda^{238} \mathrm{t}}-1\right) 206+0.0072 \frac{\mathrm{U}}{238.04}\left(\mathrm{e}^{\lambda^{235} \mathrm{t}}-1\right) 207
$$

where $\mathrm{Pb}, \mathrm{Th}$, and $\mathrm{U}$ are in $\mathrm{ppm}$ and $\lambda^{232}\left(4.9475 \times 10^{-11} \mathrm{yr}^{-1} ;[8]\right), \lambda^{235}\left(9.8485 \times 10^{-10} \mathrm{yr}^{-1}\right.$; [9]), and $\lambda^{238}$ $\left(1.55125 \times 10^{-10} \mathrm{yr}^{-1}\right.$; [9]) are the decay constants for $\mathrm{Th}^{232}, \mathrm{U}^{235}$, and $\mathrm{U}^{238}$, respectively. Solving for $t$ yields the age of the analyzed grain along with the fraction of $\mathrm{Pb}$ generated from each parent element.

From our analyses of thorite in sample $12023,147-10$, we calculate a crystallization age of $3.87 \pm 0.03 \mathrm{Ga}$ (error is a 95\% confidence interval). Analyses of yttrobetafite and monazite, which also occur in 12023,147-10, yield similar crystallization ages but with larger uncertainties. We calculate a crystallization age of $3.9 \pm 0.3$ Ga for sample 12032,366-19 from our analyses of zirconolite.

We conclude that geochronology using EPMA is an effect means to date extremely small $(\sim 1 \mu \mathrm{m})$ Th-, U-, and radiogenic $\mathrm{Pb}$-bearing phases because of modern beam stability and analytical matrix and interference corrections. In terrestrial samples, the analysis of thorite has been deemed to produce unreliable crystallization ages owing to its inability to retain radiogenic $\mathrm{Pb}[10]$. However, because similar ages were calculated from analyses of cooccurring thorite, yttrobetafite, and monazite ([10] recommend monazite for geochronology using EPMA), we think that the thorite in these lunar granite samples accurately records the crystallization age. 


\section{References}

[1] S.M. Seddio et al., Am. Min. (2012) Submitted.

[2] C. Meyer et al., M\&PS 31 (1996) p. 370-387.

[3] A.-C. Zhang et al., GCA, 10 (2012) doi: http://dx.doi.org/10.1016/j.gca.2012.07.023.

[4] S.M. Seddio et al., LPSC43 (2012) 2704.

[5] M.J. Drake and D.F. Weill, Chem. Geo., 10 (1972) p. 179.

[6] P. Carpenter et al., J. of Research of NIST, 107 (2002) p. 703.

[7] J.-M. Montel et al., Chem. Geo., 131 (1996) p. 37-53.

[8] A.H. Jaffey et al., Phys. Rev. C: Nucl. Phys., 4 (1971) p. 1889-1906.

[9] L.J. LeRoux and L.E. Glendenin, Proc. Natl. Meet. Nucl. Energy, Pretoria, South Africa (1963) p. 83-94.

[10] A. Cocherie and O. Legendre, Lithos, 93 (2007) p. 288-309.

[11] This work was funded by NASA grant NNG04GG10G (RLK).

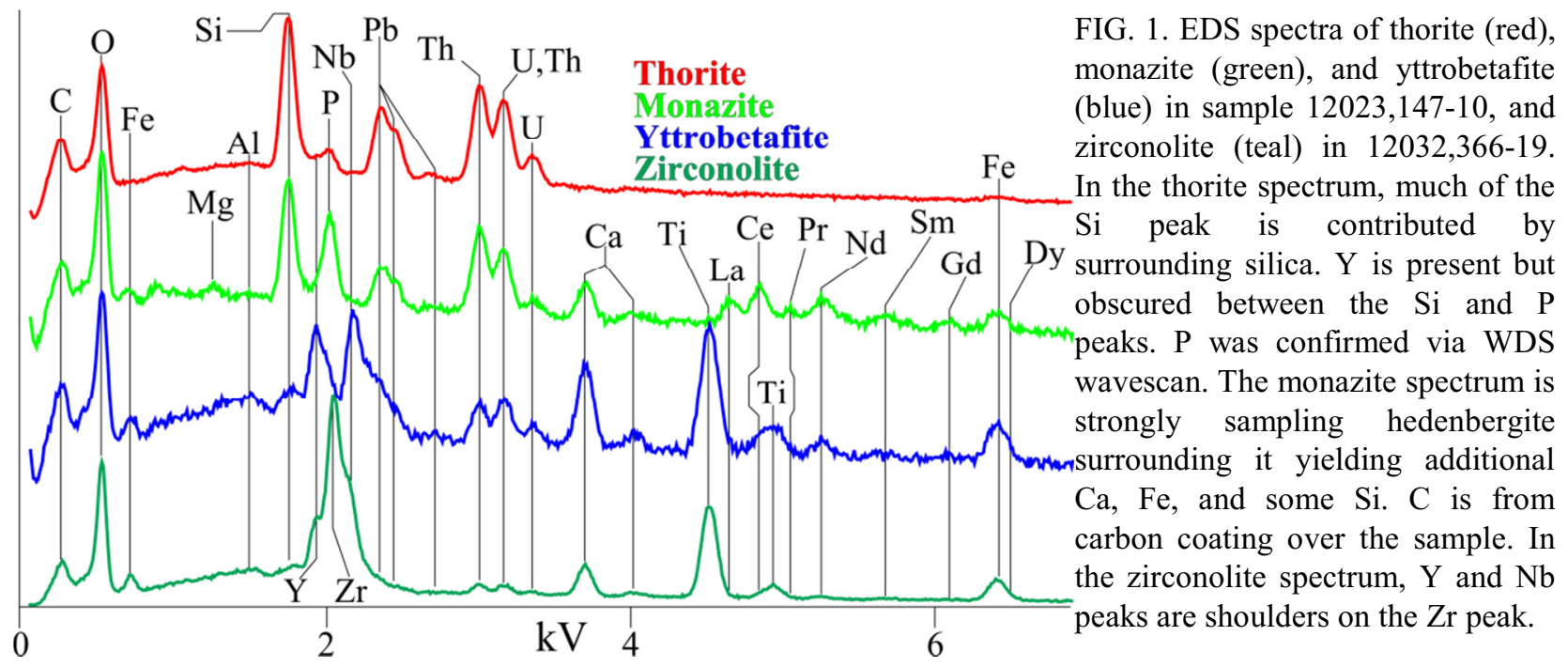

TABLE 1. Analyzed and model compositions of thorite, yttrobetafite, and monazite in 12023,147-10 and zirconolite in 12032,366-19.

\begin{tabular}{|c|c|c|c|c|c|}
\hline & Thor & Thor $^{1}$ & $Y \beta$ & Mon & Zirc \\
\hline$\overline{\mathrm{SiO}_{2}}$ & 46.5 & 17.3 & $<0.03$ & 21.5 & $<0.01$ \\
\hline $\mathrm{P}_{2} \mathrm{O}_{5}$ & - & 2.65 & $<0.03$ & 11.5 & - \\
\hline $\mathrm{Al}_{2} \mathrm{O}_{3}$ & 1.66 & 0.15 & 0.11 & 0.15 & 0.18 \\
\hline $\mathrm{ThO}_{2}$ & 0.03 & 51.0 & 5.95 & 21.9 & 2.40 \\
\hline $\mathrm{UO}_{2}$ & 25.2 & 23.3 & 3.34 & 2.09 & 1.08 \\
\hline $\mathrm{PbO}$ & 6.42 & 0 & 4.12 & 6.05 & 1.43 \\
\hline $\mathrm{Y}_{2} \mathrm{O}_{3}$ & 11.1 & 2.76 & 11.0 & 1.60 & 9.89 \\
\hline $\mathrm{RE}_{2} \mathrm{O}_{3}{ }^{*}$ & 1.62 & 2.01 & 11.3 & 21.1 & 8.89 \\
\hline $\mathrm{FeO}$ & - & 0.76 & 6.35 & 7.00 & 9.35 \\
\hline $\mathrm{CaO}$ & 0.46 & 0.13 & 7.19 & 4.98 & 4.28 \\
\hline $\mathrm{TiO}_{2}$ & - & - & 23.1 & 0.22 & 24.3 \\
\hline $\mathrm{ZrO}_{2}$ & - & - & - & - & 28.7 \\
\hline $\mathrm{Nb}_{2} \mathrm{O}_{5}$ & - & - & 17.5 & $<0.03$ & 7.36 \\
\hline Total & 93.02 & 100.0 & 90.1 & 98.1 & 97.9 \\
\hline
\end{tabular}

Values are in $\mathrm{wt} \% . \mathrm{RE}_{2} \mathrm{O}_{3}$ * is the concentration of rare earth oxides calculated from analyzed $\mathrm{La}_{2} \mathrm{O}_{3}$, $\mathrm{Ce}_{2} \mathrm{O}_{3}$, and $\mathrm{Y}_{2} \mathrm{O}_{3}$. Thor is an analysis of thorite in 12023,147-10 with the least beam sampling of adjacent phases. Thor ${ }^{1}$ is an average of 10 analyses from which we "removed" $\mathrm{SiO}_{2}$ to achieve thorite stoichiometry and calculated initial $\mathrm{ThO}_{2}$ and $\mathrm{UO}_{2} . \mathrm{Y} \beta$ is the average of 4 yttrobetafite analyses (unanalyzed $\mathrm{WO}_{3}$ is present in WDS wavescan). "Mon" is the average of 4 monazite analyses (includes contribution from adjacent hedenbergite). "Zirc" is the average of 2 zirconolite analyses.
TABLE 2. Age calculation results from samples 12023,147 10 and 12032,366-19.

Mineral N Age 95\%

(Ga) CI

\begin{tabular}{lll}
\hline Yttrobetafite 4 & 3.84 & 0.06
\end{tabular}

\begin{tabular}{llll}
\hline Thorite & 5 & 3.87 & 0.03 \\
\hline
\end{tabular}

\begin{tabular}{llll}
\hline Monazite & 4 & 3.96 & 0.33 \\
\hline
\end{tabular}

\begin{tabular}{llll}
\hline Zirconolite & 4 & 3.87 & 0.28 \\
\hline
\end{tabular}

Yttrobetafite, thorite, and monazite are from 120023,147 10. Zirconolite is from $12032,366-19$. "95\% CI" is the 95\% confidence interval. " $\mathrm{Pb}_{\mathrm{Th}} \%$ " is the percent of $\mathrm{Pb}$ in the analyzed phase that was produced from the decay of Th. The remainder was produced from the decay of $U$. 